\title{
Insulin bolus given by sprinkler needle: effect on absorption and glycaemic response to a meal
}

\author{
BERIT EDSBERG， DORTE HERLY， PER HILDEBRANDT， CLAUS KÜHL
}

\begin{abstract}
Two studies were conducted investigating the effect of injecting short acting insulin subcutaneously by means of a sprinkler needle; this needle has 14 small holes in the wall but is sealed at the tip. In the first study absorption of $8 \mathrm{U}$ iodine-125 labelled Actrapid HM injected subcutaneously at two separate sites in the abdominal wall was measured in 10 patients. One injection was given with the sprinkler needle and the other with a conventional needle. The initial dose absorbed during the first 30 minutes was significantly higher with the sprinkler needle. In the second study $10 \mathrm{U}$ Actrapid HM was given to 11 other patients (all negative for $C$ peptide and with low insulin binding antibody titres) on two separate days immediately before a standardised breakfast either by the sprinkler needle or by a conventional needle (random order). Plasma free insulin increased more rapidly and to higher concentrations with the sprinkler needle and the glycaemic response was considerably diminished.

The sprinkler needle improves both the insulin absorption rate and the glycaemic response to a meal and may reduce the 30 minutes or so before meals that diabetics must inject to minimise postprandial hyperglycaemia.
\end{abstract}

\section{Introduction}

In non-diabetic subjects a steep increase in the plasma insulin concentration occurs in response to a meal and between meals concentrations are low and comparatively stable. ${ }^{1}$ In an effort to mimic this "normal" pattern an increasing number of diabetic patients now follow a regimen of injecting fast acting insulin before the main meals and long or intermediate acting insulin at bedtime (the so called basal-bolus regimen). ${ }^{23}$ Compared with the insulin

Hvidøre Hospital, Emiliekildevej 1, DK-2930 Klampenborg, Denmark BERIT EDSBERG, MD, senior registrar

DORTE HERLY, MD, registrar

PER HILDEBRANDT, MD, registrar

CLAUS KUHL, MD, chief physician

Correspondence and requests for reprints to: Dr Edsberg. peaks induced by meals in non-diabetics, however, those in insulin treated diabetics show a less steep rise and fall and the maximum concentration is lower. A possible explanation may be that maximum insulin absorption takes place only after the injected insulin has achieved diffusion equilibrium in the tissue. ${ }^{+-6}$

We decided to see whether subcutaneous injection of short acting insulin by means of a special needle containing 14 small holes in the wall but sealed at the tip (sprinkler needle) might improve the absorption rate of insulin and hence diminish the glycaemic response to a meal.

\section{Materials, subjects, and methods}

The sprinkler needle is an ordinary $25 \mathrm{~mm}$ multi-injection needle with an inner diameter of $0.5 \mathrm{~mm}$ but with 14 holes set in the wall $5-15 \mathrm{~mm}$ from the tip, which is sealed. The total square area of the 14 holes is equal to the square area of the original outlet. For comparison as a "conventional" needle a similar but unmodified needle was used. For all injections, which were given at an angle of 45 degrees, the whole length of the needle was inserted. The sprinkler needle is experimental and has been used only in our studies. Figure 1 shows the action of the needle.

\section{ABSORPTION STUDY}

Ten patients (three women, seven men) with a history of insulin dependent diabetes mellitus for a mean of 18 years (range 1-28 years) participated in the absorption study. Their mean age was 32.2 years (range 19-50), height $176.8 \mathrm{~cm}$ (range $156-188 \mathrm{~cm}$ ), and weight $68.9 \mathrm{~kg}$ (range $55-84 \mathrm{~kg}$ ). After an overnight fast and abstinence from smoking the patients took their normal breakfast followed by $200 \mathrm{mg}$ potassium iodine to block the thyroid. Eight units of iodine-125 labelled insulin (Actrapid HM $40 \mathrm{U} / \mathrm{ml}$, specific activity $0.056-0.074 \mathrm{MBq} / \mathrm{ml}$ ) was injected subcutaneously at two separate sites in the abdominal wall roughly $5 \mathrm{~cm}$ distal to the umbilicus and $7 \mathrm{~cm}$ from the midline. One injection was given with the conventional needle and the other with the sprinkler needle, the injection sites being chosen at random. All injections were given at an angle of 45 degrees.

Emission of $\gamma$ rays was measured continuously with two stationary gammacounters $(5 \times 5 \mathrm{~cm} \mathrm{Na}$-I scintillation detectors), readings being taken initially every five minutes and later every 10 minutes for up to eight hours after the injections or until the residual activity was less than $5-10 \%$ of the initial value. All counts were corrected for background activity and the 


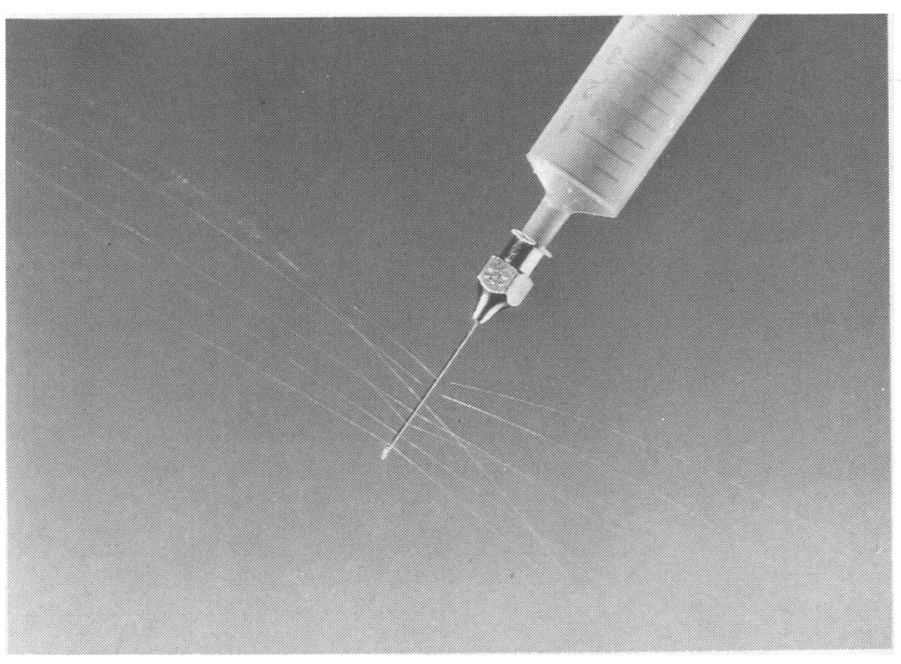

FIG l-Action of sprinkler needle.

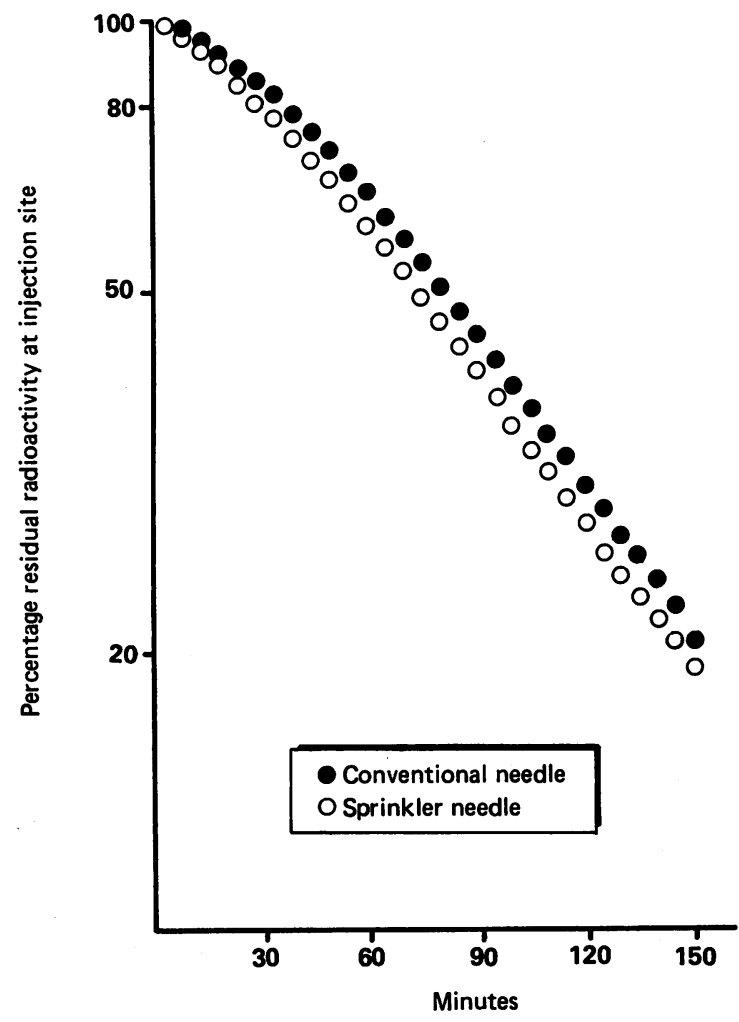

FIG 2-Mean percentage residual radioactivity at injection site comprared with percent of initial.
$52-83 \mathrm{~kg}$ ). The patients had a plasma $\mathrm{C}$ peptide concentration of less than $0.05 \mathrm{pmol} / \mathrm{l}$ six minutes after $1 \mathrm{mg}$ glucagon intravenously, and their mean concentration of insulin binding antibodies was low $(0.361 \mathrm{U} / \mathrm{l}$; range $0.017-1.967 \mathrm{U} / \mathrm{l}$ ). None of the patients had diabetic nephropathy, two had symptoms of peripheral neuropathy, and seven had background retinopathy. Before the study five patients were having two insulin injections daily, one a single injection daily, and five were using insulin pumps; the mean daily insulin dose was $38 \cdot 2 \mathrm{U}$ (range 20-52 U). The mean glycosylated haemoglobin value was $8 \cdot 8 \%$ (range $6 \cdot 2-9 \cdot 7 \%$; normal range $4 \cdot 1-6 \cdot 1 \%$ ).

Patients were admitted to hospital the day before testing. None had received intermediate acting insulin for $\mathbf{3 6}$ hours or long acting insulin for 48 hours before the study. Blood glucose concentration was kept between 8 and $12 \mathrm{mmol} / \mathrm{l}$ during these periods by repeated injections of $4-8 \mathrm{U}$ fast acting insulin. At 7 am next morning a cannula was inserted and at 8 am

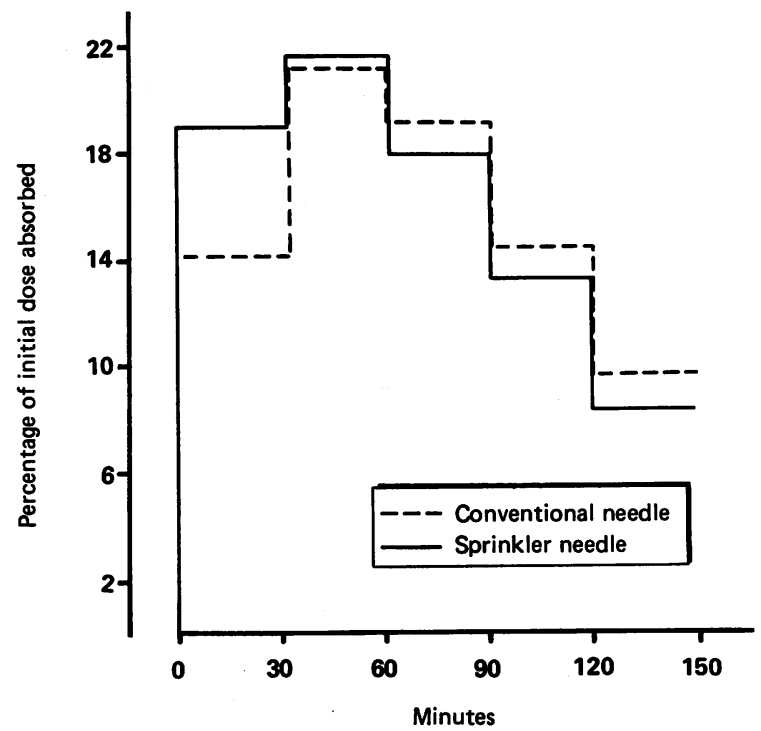

FIG 3-Mean percentage of initial insulin dose absorbed during consecutive 30 minute periods (calculated from data in fig 2).

(immediately before a standardised breakfast) $10 \mathrm{U}$ insulin (Actrapid HM $100 \mathrm{U} / \mathrm{ml}$ ) injected subcutaneously in the abdomen either by the sprinkler or by the conventional needle. Blood samples were drawn for estimation of blood glucose and plasma free immunoreactive insulin concentrations at $-60,-15,0,15,30,45,60,75,90,105$, and 120 minutes. The aim was to keep the blood glucose concentration between 8 and $12 \mathrm{mmol} / \mathrm{l}$ for the rest of the day by repeated injections of small doses of fast acting insulin. The same procedure was repeated the next morning with the other needle. On the two days of the meal tests fasting blood glucose and plasma free insulin concentrations were equal.

Blood samples were drawn into chilled heparin tubes containing $500 \times 10^{6}$ kallidinogenase inactivating units of aprotinin per 1 blood and plasma stored at $-25^{\circ} \mathrm{C}$ for later analysis of glucose ${ }^{7}$ and free insulin. ${ }^{8}$ All individual samples were run in the same assay in order to avoid interassay errors.

\section{ETHICS AND DATA HANDLING}

All patients gave informed consent to the study, which was approved by the local ethics committee.

Data from the absorption study were presented as mean values (figs 2 and 3) and data from the meal test study as means and SEM (figs 4 and 5). In both studies significance was tested by the paired Wilcoxon rank sum test. Differences resulting in p values below 0.05 were considered to be significant. The residual activity after injection plotted in figure 2 was measured at five minute intervals.

\section{Results}

The sprinkler needle gave rise to significantly lower residual activity from 20 to 70 minutes after the insulin injection (fig $2 ; p<0.05$ ). Calculation of the 
TABLE I-Timing of significant differences in increase in plasma insulin and blood glucose values between the two methods of injection

\begin{tabular}{|c|c|c|c|c|c|c|c|c|}
\hline \multirow[b]{3}{*}{ Case No } & \multicolumn{6}{|c|}{ Increase in plasma insulin $(\mathrm{pmol} / \mathrm{l})$} & \multirow{2}{*}{\multicolumn{2}{|c|}{$\frac{\text { Increase in blood glucose }(\mathrm{mmol} / \mathrm{l})}{60 \mathrm{~min}}$}} \\
\hline & \multicolumn{2}{|c|}{$15 \mathrm{~min}$} & \multicolumn{2}{|c|}{$45 \mathrm{~min}$} & \multicolumn{2}{|c|}{$60 \mathrm{~min}$} & & \\
\hline & $\begin{array}{l}\text { Sprinkler } \\
\text { needle }\end{array}$ & $\begin{array}{l}\text { Conventional } \\
\text { needle }\end{array}$ & $\begin{array}{l}\text { Sprinkler } \\
\text { needle }\end{array}$ & $\begin{array}{l}\text { Conventional } \\
\text { needle }\end{array}$ & $\begin{array}{l}\text { Sprinkler } \\
\text { needle }\end{array}$ & $\begin{array}{l}\text { Conventional } \\
\text { needle }\end{array}$ & $\begin{array}{l}\text { Sprinkler } \\
\text { needle }\end{array}$ & $\begin{array}{l}\text { Conventional } \\
\text { needle }\end{array}$ \\
\hline 1 & 320 & 95 & 500 & 375 & 410 & 355 & $1 \cdot 35$ & $1 \cdot 3$ \\
\hline 2 & 245 & 50 & 575 & 285 & 560 & 365 & $3 \cdot 15$ & $3 \cdot 2$ \\
\hline 3 & 90 & 105 & 270 & 180 & 270 & 165 & $4 \cdot 35$ & $7 \cdot 6$ \\
\hline 4 & 140 & 245 & 285 & 370 & 395 & 395 & $3 \cdot 15$ & 2.75 \\
\hline 5 & 235 & 0 & 515 & 330 & 485 & 270 & 5.95 & $7 \cdot 35$ \\
\hline 6 & 160 & 80 & 305 & 240 & 225 & 200 & $2 \cdot 3$ & $2 \cdot 25$ \\
\hline 7 & 35 & 70 & 200 & 255 & 195 & 270 & $5 \cdot 3$ & 6.55 \\
\hline 8 & 175 & 110 & 750 & 520 & 650 & 545 & $1 \cdot 45$ & $1 \cdot 6$ \\
\hline 9 & 60 & -10 & 290 & 220 & 355 & 285 & $6 \cdot 4$ & $8 \cdot 4$ \\
\hline 10 & 95 & -85 & 295 & 225 & 525 & 335 & $7 \cdot 6$ & 8.9 \\
\hline 11 & 175 & 110 & 510 & 455 & 415 & 460 & $-4 \cdot 4$ & 0.05 \\
\hline Mean (SEM) & $157 \cdot 27(25 \cdot 93)$ & $70 \cdot 00(25 \cdot 50)$ & $408 \cdot 64(51 \cdot 34)$ & $314 \cdot 09(32 \cdot 18)$ & $407 \cdot 73(42 \cdot 88)$ & $331 \cdot 36(33 \cdot 38)$ & $3.33(0.99)$ & $4.54(0.98)$ \\
\hline $\begin{array}{l}z \text { Value } \\
\text { p Value }\end{array}$ & & & & & & & & \\
\hline
\end{tabular}

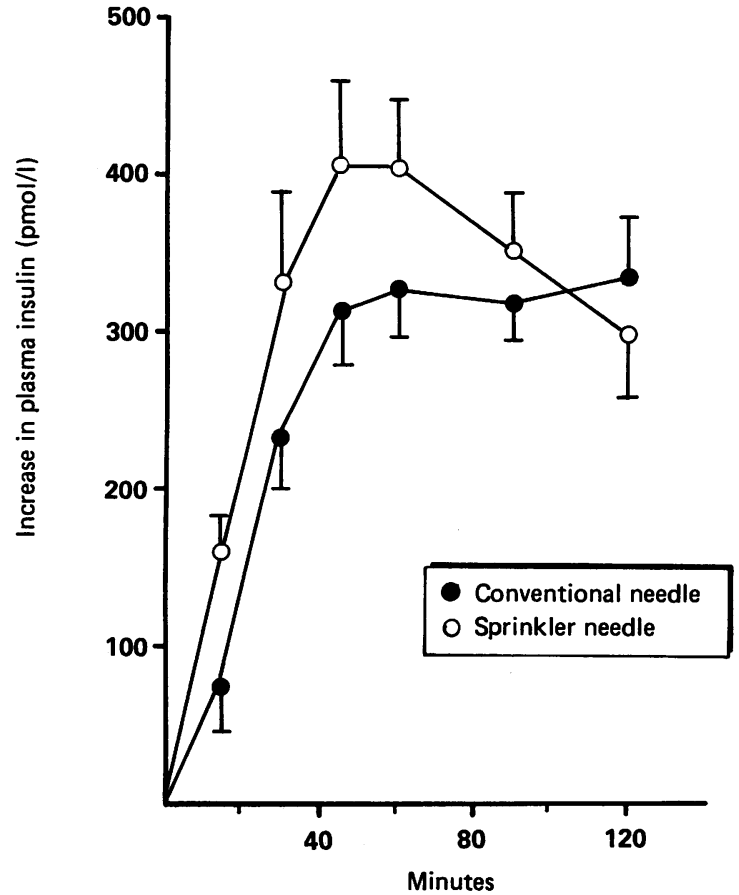

FIG 4-Mean (SEM) changes in plasma free insulin concentrations during intake of standardised breakfast preceded by subcutaneous injection of insulin by sprinkler or conventional needle.

TABLE II-Areas under insulin and glucose curves with the two methods of injection

\begin{tabular}{|c|c|c|c|c|}
\hline \multirow[b]{3}{*}{ Case No } & \multicolumn{4}{|c|}{ Area under curve $(0-120 \mathrm{~min})$} \\
\hline & \multicolumn{2}{|c|}{ Insulin (pmol/1/min) } & \multicolumn{2}{|c|}{ Blood glucose (mmol/1/min) } \\
\hline & $\begin{array}{l}\text { Sprinkler } \\
\text { needle }\end{array}$ & $\begin{array}{l}\text { Conventional } \\
\text { needle }\end{array}$ & $\begin{array}{l}\text { Sprinkler } \\
\text { needle }\end{array}$ & $\begin{array}{l}\text { Conventional } \\
\text { needle }\end{array}$ \\
\hline $\begin{array}{r}1 \\
2 \\
3 \\
4 \\
5 \\
6 \\
7 \\
8 \\
9 \\
10 \\
11\end{array}$ & $\begin{array}{l}43 \cdot 800 \\
50 \cdot 250 \\
23 \cdot 925 \\
33 \cdot 863 \\
54 \cdot 413 \\
25 \cdot 163 \\
20 \cdot 288 \\
54 \cdot 375 \\
32 \cdot 063 \\
40 \cdot 463 \\
37 \cdot 988\end{array}$ & $\begin{array}{l}36 \cdot 565 \\
31 \cdot 568 \\
17 \cdot 438 \\
\cdot 38 \cdot 288 \\
36 \cdot 375 \\
19 \cdot 575 \\
27 \cdot 300 \\
44 \cdot 438 \\
23 \cdot 588 \\
30 \cdot 038 \\
41 \cdot 925\end{array}$ & $\begin{array}{r}66 \\
309 \\
615 \\
225 \\
632 \\
244 \\
389 \\
112 \\
546 \\
647 \\
-422\end{array}$ & $\begin{array}{r}56 \\
342 \\
746 \\
177 \\
651 \\
256 \\
440 \\
123 \\
797 \\
827 \\
16\end{array}$ \\
\hline $\begin{array}{l}\text { Mean }(\text { SEM }) \\
\text { z Value } \\
\text { p Value }\end{array}$ & $\begin{array}{r}37 \cdot 870(3 \cdot 640) \\
2 \\
0\end{array}$ & $\begin{array}{l}31 \cdot 550(2 \cdot 690) \\
28 \\
62\end{array}$ & $\begin{array}{r}305 \cdot 73(92 \cdot 21) \\
2 \cdot \\
0\end{array}$ & $\begin{array}{l}402 \cdot 82(92 \cdot 47) \\
117 \\
208\end{array}$ \\
\hline
\end{tabular}

percentage of the initial dose absorbed during consecutive 30 minute periods showed absorption in the first period to be significantly faster with the sprinkler needle than with the conventional needle (fig $3 ; \mathrm{p}<0 \cdot 02$ ).

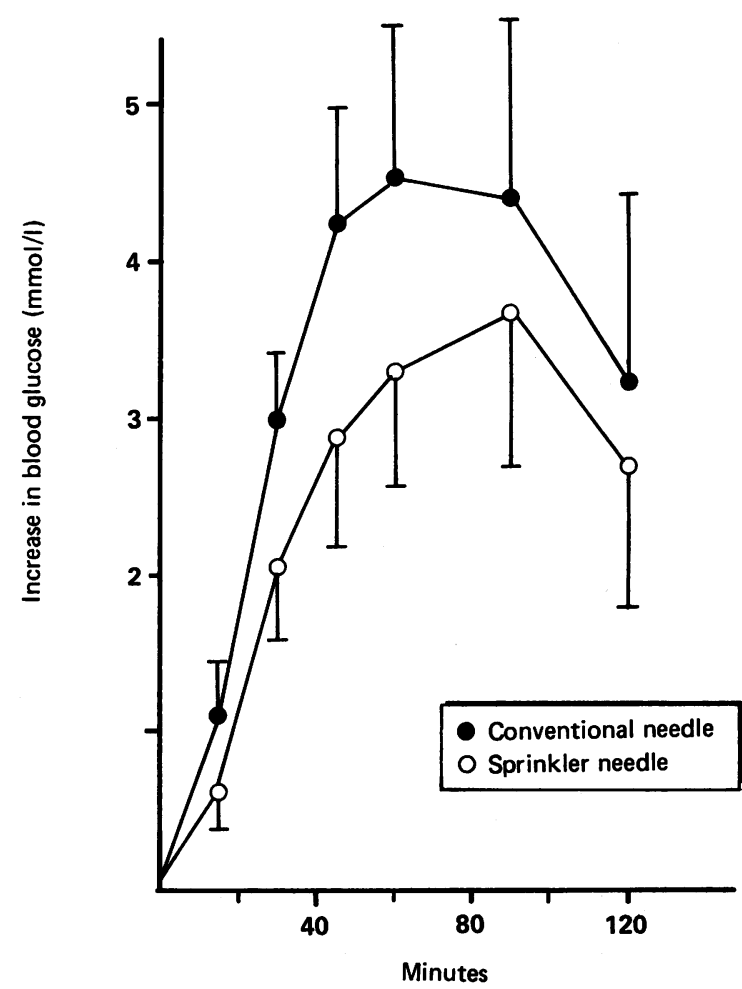

FIG 5-Mean (SEM) changes in blood glucose concentrations during intake of standardised breakfast preceded by subcutaneous injection of insulin by sprinkler or conventional needle.

In the meal test study plasma free insulin increased more rapidly and to higher concentrations when the sprinkler needle was used as compared with the conventional needle, differences being significant at 15,45 , and 60 minutes after injection (table I, fig 4; $p<0.05$ ). When the sprinkler needle was used the area under the insulin curve from time zero to 120 minutes (38 SEM 3.6) $\mathrm{pmol} / 1 / \mathrm{min}$ ) was significantly greater than that when the conventional needle was used $(32(2 \cdot 7) \mathrm{pmol} / 1 / \mathrm{min})($ table II; $\mathrm{p}<0.05)$. The glycaemic response was considerably diminished when insulin was injected with the sprinkler needle ( $306(\mathrm{SEM} \mathrm{92)} \mathrm{mmol} / \mathrm{l} / \mathrm{min}$ ) as compared with the conventional needle $(403(92) \mathrm{mmol} / 1 / \mathrm{min})($ table II; $\mathrm{p}<0.05)$. The increase in blood glucose showed a significant difference only 60 minutes after the injection (table I, fig $5 ; \mathrm{p}<0.05$ ). 


\section{Discussion}

This study shows that the initial absorption of short acting insulin is faster when insulin is injected with a sprinkler needle compared with injection by a conventional needle.

Previous studies have shown that after subcutaneous injection of fast acting insulin transport in the interstitial space and thus absorption are subject to the rate limiting effects of diffusion conditions and distance. ${ }^{+}$Absorption from the depot during the first 15 to 60 minutes after injection is comparatively slower than during the later phase. ${ }^{5}$ An explanation for this so called lag phase phenomenon may be that after injection diffusion equilibrium must occur before constant and maximal insulin absorption can take place. This is supported by the lag phase that occurs in the initial stage of a continuous subcutaneous insulin infusion but which disappears when the infusion is stopped. ${ }^{6}$ Thus we have found that by spreading the injected insulin in the tissue with the aid of a sprinkler needle the insulin absorption rate is increased.

To examine the clinical importance of our finding we carried out a meal test. The results showed that plasma free insulin increased more rapidly and reached higher concentrations when using the sprinkler needle as compared with a conventional needle and that the glycaemic response to a meal was significantly smaller when the sprinkler needle was used.

The initial absorption rate of insulin may also be increased by employing jet injection devices, which produce a more rapid increase in plasma free insulin than after injection with a conventional needle. ${ }^{y-11}$ Jet injection devices, however, need regular maintenance, are inconvenient to carry, and are expensive; hence they are not widely used." '?
The sprinkler needle is as easy to use as a conventional needle and may reduce the 30 minutes or so before meals that diabetic patients must inject ${ }^{13}$ to minimise postprandial hyperglycaemia.

\section{References}

1 Holman RR, Turner RC. A practical guide to basal and prandial insulin therapy. Diabetic Medicin 1985;2:25-53.

2 Jefferson IG, Marteau TM, Smith MA, Baum JD. Multiple injection regimen using an insulin injection pen and pre-filled cartridged soluble human insulin in adolescents with diabetes. Diabetic Medicine 1985;2:493-7.

3 Saurbrey N, Arnold-Larsen S, Møller-Jensen B, Kühl C. Multiple insulin injections with the NovoPen or CSII treatment: a randomised clinical trial [Abstract 1290]. Diabetes Research and NovoPen or CSII treatment: a rand

4 Hildebrandt P, Sejersen P, Nielsen SL, Birch K, Sestoft L. Diffusion and polymerization determines the insulin absorption from subcutaneous tissue in diabetic patients. Scand $\mathcal{J}$ Clin Lab Invest 1985;45:685-90.

5 Binder C. Absorption of injected insulin. Copenhagen: Munksgaard, 1969

6 Hildebrandt P, Birch K. Nielsen SL, Sestoft L. Absorption of infused insulin: kinetics and relation to subcutaneou. hlood flow. Diabetologia 1983;25:164.

7 Trinder P. Determination of glucose in blood using glucose oxidase with an alternative oxygen acceptor. Ann Clin Biochem 1969;6:24-7.

$8 \mathrm{Kühl} \mathrm{C,} \mathrm{Holst} \mathrm{JJ}$. Plasma glucagon and the insulin:glucagon ratio in gestational diabetes. Diabetes 1986;25:16-23.

9 Taylor R, Home PD, Alberti KG. Plasma free insulin profiles after administration of insulin by jet and conventional syringe injection. Diabetes Care 1981;4:377-9.

10 Pehling GB, Gerich JE. Comparison of plasma insulin profiles after subcutaneous administration of insulin by jet spray and conventional needle injection in patients with insulin dependent diabetes mellitus. Mayo Clin Proc 1984;59:751-4.

11 Perriello G, Feo P De, Ventura MM, Cosmo S De, Lolli C, Pippi R. Jet insulin improves postprandial glycemic control in IDDM [Abstract 459]. Diabetes 1985;34:suppl 1 .

12 Anonymous. Jet injection of insulin [Editorial]. Lancet 1985;i:1140.

13 Kinmonth AL, Baum JD. Timing of pre-breakfast insulin injection and postprandial metabolic control in diabetic children. $\mathrm{Br} M e d \mathcal{F}$ 1980;280:604-6.

(Accepted 27 March 1987)

\section{YEARS AGO}

Another Report of the evidence collected by the Royal Commission on Education has been issued, and, though it consists of over 1,000 pages, it contains nothing beyond the evidence taken down to April 6th and the syllabus of points for inquiry. The latter is concerned with many matters of great importance to school-boards and the teaching profession, such as the state of laws, codes, and grants, the consideration of cost and grievances.

The good of the child as an individual and as a unit in society is the object which national education should seek to attain, and we look in vain for any special attention given by the Commissioners to ascertaining from competent authorites the actual condition of health, strength, and growth of our schoolpopulation. The reason of this omission is not far to seek when we look at the lists of Commissioners and witnesses, for no member of the medical profession appears among those concerned in compiling the volume. It is very desirable that, before the Commission has concluded its work, some direct and impartial evidence should be collected as to the condition of the children as seen in our primary schools. A good deal of evidence is published about the teaching of science to the children; and it may be presumed that those who desire this kind of instruction to be given are possessed of scientific training, and they ought, therefore, to be able to see the propriety of instituting a scientific inquiry as to the actual condition of the children, to be made by those who would be competent to observe for themselves, and not be dependent entirely upon the opinions of teachers.

Two important references in the points given for inquiry remain without satisfactory answer in evidence thus far. "Is it (that is, the quantity of knowledge demanded) such as to cause over-pressure? Definition of overpressure." Here we come upon a question of great importance, a problem that requires the best skill of the medical profession. This term, "overpressure," which we so often meet with in the evidence, is not a medical term; but the physical effects of too much school work, or anything else that exhausts and deprives of strength, may be determined by observation. Before witnesses are questioned as to whether over-pressure exists in their schools, the Commission should define what is meant by this condition, and how other people can see it when they look at children in schools.

Another disadvantage, which flows from the unfortunate mistake which the Committee has made, in taking only the opinion of teachers on the condition of the children, is that any defects found in them are likely to be attributed to some of those conditions only which the teacher sees. The condition of many children in our schools, besides those "over-pressed," demands attention; the blind and the dumb are to some extent cared for, but what pains are taken by the Education Department to train the badly made feeble brains, to check the development of myopia, to ascertain whether intelligent children - who suffer from frequent headaches, as many do, or who occasionally have a fit-are educated or excused attendance at school on account of ill-health, to their own disadvantage and the public loss? The evidence of many school teachers shows abundantly, what is well known, that a hard-and-fast rule for educating children is not what will produce the best effects. Teachers and Her Majesty's Inspectors seem to differ in methods of diagnosing the child's condition, but both are apt to think that they can recognise the child's state of health by instinct and practice, whereas the real condition of the child can only be determined by scientific observation. (British Medical Fournal 1887;ii:30.)

The House of Lords has taken a step of great public importance in appointing a Select Committee on the subject of the abatement of the smoke nuisance. It is to be hoped that the Committee will at once proceed to take evidence. We all want to know what further resources in the way of abating this nuisance are actually available. Since the question was inquired into thirty years since by Lord Palmerston's Committee, no official report has been made on the subject. It is, however, well known that enormous progress has been made in all practical as well as scientific details, and even principles connected with the economic and smokeless consumption of fuel both for domestic and manufacturing purposes. Very little of this available knowledge is, however, largely utilised, or, indeed, adequately apprehended either by private individuals or manufacturing firms. It is monstrous that where so much can be done so little is done. In 1887 we are but little ahead in common practice of 1853. The mere taking of evidence and focussing existing information in an official publication would itself be of great public service. (British Medical Fournal 1887;ii:32.) 